\title{
Inovasi Guru dalam Pembelajaran Masa Pandemi Covid-19
}

\author{
${ }^{1}$ Khoerul Anam, ${ }^{2}$ Slamet Yahya \\ ${ }^{1}$ Pasca PGMI IAIN Purwoketo \\ ${ }^{2}$ Dosen IAIN Purwokerto \\ Email Korespondensi: anamadanaz@gmail.com
}

\begin{tabular}{l}
\hline Article Info \\
Article history: \\
Article Accepted: May 192021 \\
Publication : July 05 2021 \\
\end{tabular}

Keywords:

Innovation, teachers, learning and the Covid pandemic 19

\author{
Article Info \\ Article history: \\ Article Accepted: May 192021 \\ Publication : July 052021
}

Keywords:

Inovasi, guru, pembelajaran dan masa pandemi covid 19

\begin{abstract}
Learning must be able to run well under any conditions, both normal conditions and emergency conditions. Learning is a need that must be fulfilled properly. Good learning will produce a good generation. Learning in a pandemic period demands creativity and innovation from educators so that learning can run in any condition. In this study, it discusses teacher innovation in learning during the Covid 19 pandemic which demands creativity and innovation because it occurs suddenly as a natural disaster. The results show that The teacher remains enthusiastic in facing learning during the Covid 19 pandemic by trying to continue to carry out learning by innovating in learning methods and using existing learning media, providing materials and a fun evaluation system.
\end{abstract}

\begin{abstract}
Abstrak
Pembelajaran harus bisa berjalan baik dalam kondisi apapaun, baik kondisi normal maupun kondisi darurat. Pembelajaran merupakan kebutuhan yang harus dipenuhi dengan baik. Pembelajaran yang baik akan menghasilkan generasi yang baik. Pembelajaran dalam masa pandemi menuntut kreatifitias dan inovasi dari pendidik supaya pembelajaran bisa berjalan dalam kondisi apapun.dalam penelitian ini membahas Inovasi guru dalam pembelajaran masa pandemi covid 19 yang sangat menuntut kreativitas dan inovasi karena terjadi dengan tiba-tiba sebagai musibah alam.Hasil penelitian menunjukan bahwa guru tetap bersemangat dalam menghadapi pembelajaran masa pandemi covid 19 dengan berusaha tetap melaksanakan pembelajaran dengan berinovasi pada metode pembelajaran dan pengunaan media pembelajaran yang ada, menberikan materi -materi substansi dan sistem evaluasi yang menyenangkan.

This is an open access article under the Lisensi Creative Commons AtribusiBerbagiSerupa 4.0 Internasional
\end{abstract}

Corresponding Author:

Khoerul Anam

Pasca PGMI IAIN Purwoketo

Email: anamadanaz@gmail.com

\section{PENDAHULUAN}

Proses pembelajaran di dunia pendidikan terus mengalami perubahan dan pembaruan, pada masa lalu proses pembelajaran sangat bertumpu pada guru sebagai sumber yang esensial dalam belajar, namun dengan perkembangan teknologi dan juga metode pembelajaran itu sendiri, guru pun tidak satu-satunya sumber belajar, tetapi banyak hal yang bisa dijadikan sumber. pembelajaran bahkan ketika pembelajaran wajib berfokus pada siswa, di mana siswa juga menjadi sumber belajar.

Guru sebagai pendidik juga harus mampu mengikuti perubahan yang terjadi dalam dunia pendidkan, agar pembelajaran tidak lagi menggunakan metode lama yang membuat pembelajaran menjadi membosankan dan membosankan bagi peserta didik, seorang pendidik 
dituntut untuk dapat memberikan pembelajaran yang menyenangkan bagi peserta didik, tentunya dengan berbagai macam bentuk inovasi. dalam belajar

Penjelasan tentang pengertian inovasi menurut Barnet sebagaimana dikutip Syafrudin dalam bukunya yang berjudul inovasi pendidikan menjelaskan bahwa definisi inovasi adalah "pembaharuan", baik berupa ide atau gagasan, tingkah laku atau objek, sebagaimana yang dinyatakan bahwa "An innovation is here defined as any thought, behavior, or thing that is new because it is qualitatively different from existing forces"

Pengertian inovasi juga di jelaskan oleh beberapa ahli lain yaitu inovasi adalah upaya untuk menemukan objek baru dengan terlibat dalam penemuan dan penemuan. Para ahli yang menyampaikan makna inovasi salah satunya menurut Karyadi dalam buku yang dinukul oleh Mulyasa, (2012) menjelaskan makna inovasi sebagai proses mengadaptasi ide praktis atau objek baru untuk digunakan di dalam kelas oleh pendidik.

Dari makna inovasi diatas dapat diambil suatu pemahaman bahwa inovasi adalah ide atau pemikiran yang nantinya diterapkan untuk menginnovasi sesuatu guna mengembangkan ilmu/konteks lebih baik lagi

Adapun para pakar pendidikan banyak yang mengartikan belajar, salah satunya yakni sebagaimana di jelaskan oleh Ridwan Abdulah yang dinukil oleh Nurdyansyah dan Eni Fariyatul Fahyuni dalam bukunya inovasi model pembelajaran, bahwa belajar pada dasarnya merupakan peristiwa yang bersifat individual yakni peristiwa terjadinya perubahan tingkah laku sebagai dampak dari pengalaman individu. Sementara itu, pembelajaran adalah penyediaan kondisi yang mengakibatkan terjadinya proses belajar pada diri peserta didik, sedangkan menurut siti Amminah di jelaskan bahwa belajar adalah suatu proses yang dilakukan individu untuk memperoleh perubahan tingkah laku yang baru sebagai pengalman individu itu sendiri, dan ditekankan juga bahwa belajar adalah suatu proses dan bukan hasil

Adapun pengertian belajar menurut slavin sebagaimana dikutip oleh faturohman bahwa belajar adalah perbahan yang relatif permanen dalam tingkah laku sebagai pengalaman atau latihan yang diperkuat.

Pengertian belajar juga di jeaskan oleh gagne Gagne sebagaimana dikutip oleh faturahman bahwa belajar merupakan suatu perubahan yang diperlihatkan dalam perubahan tingkah laku yang keadaannya berbeda dari sebelum individu berada dalam situasi belajar dan sesudah melakukan tindakan yang serupa itu. Pemahaman lainnya mengenai belajar menuut Makki dan Maflahah bahwa belajar m adalah kegiatan yang dilakukandengan sengaja atau tidak sengaja oleh setiap individu, sehingga terjadi perubahan dari tidak tahu menajdi tahu atau dapat dikatakan bahwa belajar merupakan prosesperubahan individu yaang berinteraksi dengan lingkungan sekitarnya kearah yang lebih baik maupun tidak baik. Adapun Menurut Burton dalam Usman dan Setiawati dijelaskan bahawa belajar merupakan perubahan tingkah lau pada diri individu lain dan individu dengan ingkunganya sehingga mereka lebih mampu berinteraksi denagn lingkunganya

Dari berbagai pengertian beajar dapat ditarik kesimpulan bahwa belajar merupakan proses mengenali berbagai sesuatu seperti keterampilan, pengetahuan dan sikap yang dapat mengubah seseorang dari tidak bisa menjadi bisa. Sehingga pembelajaran adalah sebuah sistem pendidikan yang membentuk seseorang untuk mampu belajar guna mencapai tujuan yang telah ditetapkan.

Jadi yang dimaksud dengan inovasi pembelajaran yaitu proses belajar pada siswa yang dirancang, dikembangkan dan dikelola secara kreatif, dinamis, dengan menerapkan pendekatan multi kearah yang lebih baik, untuk menciptakan suasana dan proses pembelajaran yang kondusif bagi siswa.

Adapun menurut Kamus Besar Bahasa Indonesia dijelaskan bahwa yang dimaksud dengan guru adalah orang yang pekerjaannya (mata pencahariannya, profesinya) mengajar. Pengertian ini masih sangat umum dan multi tafsir. Pengertian guru menurut (yohana alfiani:2020) disebutkan bahwa guruadalah orang deawasa yang bertanggug jawab memberi bimbingan atau bantuan anak didik dalam perkembangan jasmani dan rohaninya agar mencapai 
kedewaanya mampu melaksanakan tugasnya sebagai mahluk Allah, khalifah di muka bumi, sebagai mahluk sosial dan sebagai individu yang mampu berdiri sendiri.

Secara umum dapat diartikan bahwa guru adalah pendidik dan pengajar pada pendidikan anak usia dini jalur sekolah atau pendidikan formal, pendidikan dasar, dan pendidikan menengah. Guru-guru seperti ini harus mempunyai semacam kualifikasi formal. Dalam definisi yang lebih luas, setiap orang yang mengajarkan suatu hal yang baru dapat juga dianggap seorang guru.

Sedangkan masa pandemi disini dapat diartikan sebagaimana di sebutkan dalam wikipedia sebagai peristiwa menyebarnya wabah Penyakit koronavirus 2019 (bahasa Inggris: coronavirus disease 2019, singkatan dari COVID-19) di seluruh dunia termasuk dalam wilayah Indonesia dan juga di wilayah dan juga wilayah yang akan penulis adakan reseach yaitu Desa Pucung Lor Kecamatan Kroya Kabupaten Cilacap propinsi jawa tengah dimana ada sebuah lembaga pendidikan di dalamnya yaitu MI Ma'arif 09 Pucung Lor kecamatan Kroya Kabupaten Cilacap.

Dengan melihat kondisi pandemi covid 19 ini penulis melihat bahwa guru sangat dituntut untuk melakukan berbagai cara bagaimana proses pembelajaran tetap bisa berjalan dengan segala keterbatasan dan kondisi yang ada terutama di daerah pedesaan seperti di MI Ma'arif 09 Pucung lor, Dimana banyak persoalan yang menajdi hambatan guru dalam proses kegiatan pembelajaran. dan guru dituntut kreatifitas dan inovasi dalam pembelajaran.

Dari latar belakang permasalahan diatas penulis tertarik untuk mengadakan penelitan tentang bagaimana inovasi yang dilakukan guru MI Ma'arif 09 Pucung lor Kecamatan Kroya Kabupaten Cilacap agar pembelajaran dapat tetap berjalan dimasa padnemi Covid 19 dengan tetap menyenangkan dan materi tersampaikan.

\section{METODE PENELITIAN}

Pada Penelitian ini penulis menggunakan metode penelitian kualitatif. Metode Kulaitatif Menurut Juliansyah dijelaskan sebagai suatu proses penelitian dan pemahaman yang berdasarkan pada metodologi yang menganalisis suatu fenomena soslial dan problematika manusia. Metode ini digunakan untuk meneliti pada kondisi objek yang alamiah, (sebagai lawannya adalah eksperimen) dimana peneliti adalah sebagai instrumen kunci. Teknik pengumpulan data dilakukan secara triangulasi (gabungan) analisis data bersifat induktif, dan hasil penelitian kualitatif lebih menekankan makna dari pada generalisasi. Adapun pertimbangan penulis mengunakan metode ini adalah karena ia lebih mampu mendekatkan peneliti dengan objek yang diselidiki, sebab peneliti langsung mengamati objek yang selidiki dengan kata lain peneliti bertindak sebagai alat utama riset (human instrument).

Teknik pengumpulan data dalam penelitian kualitatif secara umum dapat dikelompokkan ke dalam dua cara yatu teknik pengumpulan data yang bersifat interaktif dan non interaktif. Tehnik pengumpulan data dalam penelitian ini meliputi ; wawancara, observasi dan dokumentasi.

Menurut Lexy J. Moleong sebagaimana dikutip suyanto dan sutinah mengartikan bahwa wawancara dengan tujuan percakapan tertentu. Dawal wawancara ini peneliti dan responden secara langsung (tatap muka) untuk memperoleh informasi secara lisan dengan memperoleh data tujuan yang bisa menjelaskan masalah penelitian. Pada teknik pengumpulan data dengan cara wawancara, maka yang dilakukan peneliti adalah dengan menanyakan langsung pada narasumber hal-hal yang akan diteliti. Metode ini digunakan untuk mengetahui tentang bagaimana upaya yang digunakan guru dalam menghadapi pembelajaran masa pandemi, meilputi materi, metode, sumber belajar, Media Pembelajaran dan Sistem Evaluasi yang digunakann dalam pembelajaran jarak jauh. Adapun nara sumber diambil dari dewan guru seluruhnya sebanyak 10 orang diantaranya: Hj Surifah, Setiyo Ariyanto, Sugiarti, Achmad Zabidi, Eva Riyanti, Feri Setaiwan, inni Nur Hidayati, Triyan Witasari, Wahyu Linda NH, dan Lukman Setiawan. 
Observasi atau pengamatan adalah kegiatan pemuatan penelitian terhadap suatu objek. Apabila dilihat pada proses pelaksanaan pengumpulan data, observasi dibedakan menjadi partisipan dan non-partisipan. Dalam observasi atau pengamatan kegiatan yang dilakukan adalah memperhatikan objek kajian/penelitian dengan seksama. Kegiatan observasi bertujuan menulis atau mencatat setiap keadaan yang relevan dengan tujuan penelitian yaitu dengan melihat langsung aktivitas guru dalam membuat, merencanakan dan melakasanakan pembelajaran masa pandemi covid 19.

Cara lain untuk memperoleh data yaitu menggunakan dokumentasi. Dengan dokumentasi peneliti memperoleh informasi dari berbagai sumber. Informasi tersebut antara lain tempat tinggal, alamat dan latar belakang pendidikan. Suharsimi Arikunto mengatakan bahwa metode dokumentasi adalah peneliti menyelidiki benda-benda tertulis seperti buku-buku, majalah, dokumen, peraturan- peraturan, notulen rapat, catatan harian dan sebagainya Untuk mendukung kelengakapan dari observasi dan wawancara maka peneliti menggunakan metode dokumentasi dengan meneliti dokumen Rencana Pembelajaran, aplikasi pembelajaran yang digunakan dan metode serta foto-foto dokumentasi yang selama Pembelajaran masa pandemi covid 19.

Menurut sandu suyoto dan ali sodik analiss data adalah Rangkaian kegiatan penelaahan, pengelompokan, sistematisasi, penafsiran dan verifikasi data agar sebuah fenomena memiliki nilai social, akademis dan ilmiah. Adapun kegiatan dalam analiss data meliputi ; mengelompokan data berdasarkan variabel dan seluruh responden, menyajikan data tiap variabel yang diteliti, melakukan perhituungan untuk menguji hoptesis, langkah terakhir tidak dilakukan

Menurut Miles \& Huberman mengatakan bahwa analisis terdiri dari tiga alur kegiatan yang terjadi secara bersamaan yaitu: reduksi data, penyajian data, penarikan kesimpulan/verifikasi.

Reduksi data diartikan sebagai proses pemilihan, pemusatan perhatian pada penyederhanaan, pengabstrakan, dan transformasi data kasar yang muncul dari catatan- catatan tertulis di lapangan. Reduksi data berlangsung terus-menerus selama proyek yang berorientasi penelitian kualitatif berlangsung. Selama pengumpulan data berlangsung, terjadilan tahapan reduksi selanjutnya (membuat ringkasan, mengkode, menelusur tema, membuat gugusgugus, membuat partisi, membuat memo). Reduksi data/transformasi ini berlanjut terus sesudah penelitian lapangan, sampai laporan akhir lengkap tersusun. Data yang berasal dari hasil wawancara dengan subyek penelitian dan dokumentasi yang didapat akan diseleksi oleh peneliti. Kemudian kumpulan data yang telah diperoleh akan dikategorikan. Mana sajakah data yang sesuai dengan masalah yang telah dirumuskan. Dalam penelitian ini reduksi data dilakukan pada saat peneliti mendapatkan data dari seluruh Guru di MI Ma'arif 09 Pucung Lor, Kecamatan Koya, Kabupaten Cilacap, lalu data disederhanakan dengan mengambil datadata yang mendukung dalam pembahasan penelitian ini. Sehingga data-data tersebut mengarah pada kesimpulan yang dapat dipertanggungjawabkan.

Miles \& Huberman memberikan batasan suatu penyajian sebagai sekumpulan informasi tersusun yang memberi kemungkinan adanya penarikan kesimpulan dan pengambilan tindakan. Mereka meyakini bahwa penyajian-penyajian yang lebih baik merupakan suatu cara yang utama bagi analisis kualitatif yang valid, yang meliputi: berbagai jenis matrik, grafik, jaringan dan bagan. Semuanya dirancang guna menggabungkan informasi yang tersusun dalam suatu bentuk yang padu dan mudah diraih. Dengan demikian seorang penganalisis dapat melihat apa yang sedang terjadi, dan menentukan apakah menarik kesimpulan yang benar ataukah terus melangkah melakukan analisis yang menurut saran yang dikisahkan oleh penyajian sebagai sesuatu yang mungkin berguna. Dalam menyajikan data dalam penelitian ini peneliti mendiskripsikan data-data tentang bagaimana inovasi pembelajaran guru dimasa pandemi covid 19.

Penarikan kesimpulan menurut Miles \& Huberman hanyalah sebagian dari satu kegiatan dari konfigurasi yang utuh. Kesimpulan-kesimpulan juga diverifikasi selama 
penelitian berlangsung. Verifikasi itu mungkin sesingkat pemikiran kembali yang melintas dalam pikiran penganalisis (peneliti) selama ia menulis, suatu tinjauan ulang pada catatancatatan lapangan, atau mungkin menjadi begitu seksama dan menghabiskan tenaga dengan peninjauan kembali serta tukar pikiran di antara teman sejawat untuk mengembangkan kesepakatan intersubjektif atau juga upaya-upaya yang luas untuk menempatkan salinan suatu temuan dalam seperangkat data yang lain. Singkatnya, makna-makna yang muncul dari data yang lain harus diuji kebenarannya, kekokohannya, dan kecocokannya, yakni yang merupakan validitasnya. Kesimpulan akhir tidak hanya terjadi pada waktu proses pengumpulan data saja, akan tetapi perlu diverifikasi agar benar-benar dapat dipertanggungjawabkan.

\section{HASIL DAN PEMBAHASAN}

\subsection{Hasil Penelitian}

Inovasi menurut Schumpeter memiliki arti, usaha mengkreasikan danmengimplementasikan sesuatu menjadi satu kombinasi sehingga,dengan inovasi seseorang dapat menambahkan nilai dari produk, pelayanan, proses kerja, dan kebijakan pendidikantidak hanya bagi lembaga pendidikantapi juga Stakeholder dan masyaraka

Menurut Wina Sanjaya dalam bukunya kurikulum dan pembelajaran inovasi diartikan sebagai sesuatu yang baru dalam situasi sosial tertentu dan digunakan untuk menjawab atau memecahkan suatu permasalahan

Secara harfiah inovasi / innovation berasal dari kata to innovate yang mempunyai arti membuat perubahan atau memperkenalkan sesuatu yang baru, inovasi kadang diartikan sebagai penemuan namun, maknanya berbeda dengan penemuan dalam arti discovery atau Invention .Discovery mempunyai makna penemuan sesuatu yang sebenarnya sudah ada sebelumnya, misalnya penggunaan model pembelajaran inkuiri dalam matapelajaran Ilmu Pengetahuan Alam, untuk meningkatka kualitas pembelajaran tersebut di Indonesia baru baru ini dikembangkan, sebenarnya model pembelajaran tersebut sudah dilaksanakan di negara - negara lain, atau model pembelajaran melalui jaringan internet. Sedangkan Invantion ,memiliki pengertian penemuan yang benar - benar baru belum tercipta sebelumnya

Nana mengartikan bahwa inovasi pembelajaran adalah upaya baru dalam prosees pembelajaran dengan menggunakan metode, pendekatan,sarana dan suasana yang mendukung untuk tercapainya tujuan pembelajaran.

Dalam inovasi pembelajaran meliputi bebrapa hal penting diantaranya : materi pembelajaran, metode pembelajaran, media pembelajaran dan sistem evaluasi.

Dalam kondisi di masa darurat pandemi covid 19 sekarang ini guru dapat memilih menggunakan beberapa metode pembelajaran sebagai alternatif dalam pembelajaran supaya materi dan tujuan pembelajaran dapat tersampaikan dan maskimal, diantara metode yang dapat menjadi pertimbangan guru dalam melaksankan pembelajaran dimaa darurat covid 19 ini antara lain:

\section{a). Project Based Learning}

Pembelajaran model based learning merupakan model pembelajaran yang melibatkan siswa dalam kegiatan pemecahan masalah dan memberikan kesempatan kepada siswa untuk bekerja secara mandiri membangun pembelajarannya sendiri, dan pada akhirnya menghasilkan produk pekerjaan siswa yang bernilai dan realistis.

Metode project based learning ini inisiatif dari hasil implikasi dari Surat Edaran Mendikbud no.4 tahun 2020. Project based learning ini memiliki tujuan utama untuk memberikan pelatihan kepada pelajar untuk lebih bisa berkolaborasi, gotong royong, dan empati dengan sesama.

Menurut Mendikbud, metode project based learning ini sangat efektif diterapkan untuk para pelajar dengan membentuk kelompok belajar kecil dalam mengerjakan projek, eksperimen, dan inovasi. Metode pembelajaran ini sangatlah cocok bagi pelajar yang 
berada pada zona kuning atau hijau. Dengan menjalankan metode pembelajaran yang satu ini, tentunya juga harus memerhatikan protokol kesehatan yang berlaku.

\section{b). Daring Method}

Sebagai salah satu alternatif metode pembelajaran yang kedua meode daring ini bisa menjadi alternatif untuk guru dalam menyampaikan materi pembelajaran. Metode daring atau metode pembelajaran dimana siswa dan guru tidak melaksanakan pembelajaran secara tatap muka melainkan secara virtual. Metode ini dapat diberikan kepada siswa untuk memanfaatkan fasilitas yang ada di rumah dengan sebaik-baiknya. Seperti membuat konten dengan menggunakan barang-barang di sekitar rumah atau melakukan semua kegiatan belajar melalui sistem online. Cara online ini sangat cocok untuk pelajar yang berada di zonal area. merah. Dengan menggunakan metode full online seperti ini, sistem pembelajaran yang disampaikan akan terus berjalan dan seluruh siswa tetap berada di rumah masing-masing dalam kondisi aman. Cara ini dilakukan oleh guru dengan memanfaatkan media wa group, google classroom, google form sebagai guru juga memanfaatkan channel. youtube sebagai media pembelajaran online.

\section{c). Luring Method}

Untuk alternatif metode pembelajaran yang ketiga yaitu metode pembelajaran secara tatap muka, metode ini merupakan salah satu alternatif dalam pembelajaran dimasa pandemi covid 19. Luring atau Offline mengacu pada model pembelajaran yang dilakukan di luar jaringan. Dalam artian, pembelajaran yang satu ini dilakukan secara tatap muka dengan memperhatikan zonasi dan protokol kesehatan yang berlaku. Metode ini sangat cocok untuk siswa di zona kuning atau hijau, terutama dengan protokol normal baru yang ketat. Dalam metode yang satu ini, siswa akan diajar secara bergiliran (model shift) untuk menghindari keramaian. Dikutip dari Kumparan, model pembelajaran offline ini disarankan oleh Menteri Pendidikan dan Kebudayaan untuk memenuhi penyederhanaan kurikulum pada masa darurat ini.

Metode ini digunakan untuk menyiasati penyampaian kurikulum agar tidak menyulitkan dalam penyampaiannya kepada siswa. Selain itu, proses pembelajaran ini juga dinilai cukup baik bagi mereka yang belum memiliki sarana dan prasarana pendukung sistem online .

\section{d). Home Visit Method}

Metode berikutnya yang bisa menjadi alternatif guru dalam pembelajaran masa daruraat ini yaitu metode home visit atau home visit metod. Sebagaimana metode lainnya, kunjungan rumah merupakan salah satu pilihan dalam metode pembelajaran selama pandemi ini. Metode ini mirip dengan kegiatan belajar mengajar yang disampaikan selama home schooling. Jadi, guru melakukan kunjungan rumah ke rumah siswa untuk waktu tertentu. Dalam prakteknya, metode ini dapat dimanfaatkan oleh guru untuk anak-anak yang tidak terjangkau pembelajaran secara online karena kondisi ekonomi yang lemah sehingga tidak dapat membeli ponsel Andriod.

\section{e). Integrated Curriculum}

Metode pembelajaran ini disampaikan oleh anggota Komisi X DPR RI Prof. Zainuddin Maliki. Dikutip dari JPNN.com, mantan Rektor Universitas Muhammadiyah Surabaya ini menyampaikan bahwa pembelajaran akan lebih efektif bila merujuk pada project base. Yang mana, setiap kelas akan diberikan projek yang relevan dengan mata pelajaran terkait.

Metode pembelajaran ini tidak hanya melibatkan satu mata pelajaran saja, namun juga mengaitkan metode pembelajaran lainnya. Dengan menerapkan metode ini, selain pelajar yang melakukan kerjasama dalam mengerjakan projek, dosen lain juga diberi kesempatan untuk mengadakan team teaching dengan dosen pada mata kuliah lainnya. 
Integrated curriculum bisa diaplikasikan untuk seluruh pelajar yang berada di semua wilayah, karena metode ini akan diterapkan dengan sistem daring. Jadi pelaksanaan integrated curriculum ini dinilai sangat aman bagi pelajar.

\section{f). Blended Learning}

Metode blended learning adalah metode yang menggunakan dua pendekatan sekaligus. Dalam artian, metode ini menggunakan sistem daring sekaligus tatap muka melalui video converence. Jadi, meskipun pelajar dan pengajar melakukan pembelajaran dari jarak jauh, keduanya masih bisa berinteraksi satu sama lain.Metode pembelajaran blended learning ini mempunyai keunggulan ; flexibel, hemat biaya dan waktu, materi interaktif dan efektif serta efisien.

Metode blended Learing ini sangat efektif bagi guru dan siswa karena guru dan siswa dapat berinteraksi langsung walaupun ada jarak diatara mereka. Adapun media yang bisa digunakan yaitu dengan menggunakan media zoomeeting ataupun googlemeet.Pembelajaran dengan metode blended learning dalam pelaksanaanya guru mengadakan pertemuan sekali setiap minggu selebihnya secara daring. Pertemuan digunakan untuk mengumpulkan tugas-tugas dan projek yang telah di jelaska oleh guru pada waktu pembelajaran daring.

Dari beberapa metode tersebut diharapkan para guru dapat memanfaaatkan dan mengaplikasikan denagnharapan pembelajaran di masa darurat dapat berjalan denagn lancar dan materi tersampaikan ke peserta didik dengan keterbatasan yang ada namun hasil bisa semaksimal mungkin walaupun tentunya tidak sama dengan kondisi normal pada umumnya.

\subsection{Pembahasan}

Berdasarkan hasil penelitan dengan melihat data-data yang kami peroleh hasil observsi, wawancara dan dokumentasi bahwa dalam menghadapi masa pandemi yang belum tahu kapan berakhirnya, guru tetap memberikan pelajaran dengan menggunakan beberapa metode yang dianggap sesuai dengan sitauasi dann kondisi perekonomian orangtua wali, materi pelajaran, ketersediaan jaringan internet, SDM guru dan wali siswa, saarana dan prasarana pembelajaran..

Dari beberapa metode pembelajaran yang sering digunakan dimasa pandemi adalah metode (1) dalam jaringan, metode ini digunakan namun tidak dapat diakses oleh wali siswa yang tidak mempunayi hp andriod. (2) metode luar jaringan,metode ini digunakan sebagai salah satu alternatif yang digunakan untuk wali siswa yang tidak mepunyai andriod maupun yang mempunyai denagn bertujuan memberikan kesempatan bertemu dengan peserta didik biar terjdi interksi secara langsung dan juga memberi kesemaptan untuk siswa dan wali siswa menyelesaikan administrasi sekolah (3) metode home visit, metode ini dilakukan oleh guru dengan sistem door to door bagi siswa yang terkendala metode daring dan dan luring karena hal-hal tertentu seperti zona merah dan kondisi kesehatan siswa atau lainya.(4) metode projek basic learning, untuk metode ini sangat disenangi siswa karena siswa dapat mengekspresikan diri dengan membuat konten- konten yang sekaligus sebagai tugas dari gurunya.Adapun untuk 3 metode lainya juga bisa diterapkan oleh sebagaian guru sesuai dengan Sumber Daya Manusia dari guru dan siswa/wali siswa serta sarana dan prasaraana.

\section{KESIMPULAN}

Dengan melihat hasil penelitan yang telah dilakukan dapat kami simpulkan bahwa inovasi pembelajaran adalah meliputi empat macam, yaitu dari materi pembelajaran, metode pembelajaran, media pembelajaran dan sistem evaluasi pembelajaran.Adapun metode pembelajran dalam masa pandemi ini ada bebrapa yang digunakan seperti projek basic learning, daring, luring, home visit, blended learning, integrated curriculum. Namun hasil penelitian 
kami yang paing sering dipergunakan guru dalam masa pandemi adalah metode dari, home visit, luring dan project basic learning.

\section{SARAN}

Inovasi guru dalam pembelajaran ini sangat penting sekali dalam dunia pendiidkan terutama dalam kondisi dimana pembelajaran tidak dapat berjalan secara normal karena keaadaan darurat. Inovasi dan kreativitas guru mutlak diperlukan untuk mengatasi problematika pembelajaran yang ada. Untuk itu menurut penulis menyarankan pertama, kepada seluruh pendidik untuk senantiasa semangat dan selalu melakukan terobosan- terobosan dan inovasi dalam pembelajaran supaya akegiatan belajar mengajar tetap bisa berjalan walaupun dalam kondisi darurat, baik darurat seperti pandemi Covid 19 maupun darurat lainya seperti bencana alam dan lain-lain.Kedua, untuk pihak pemerintah untuk senantiasa mendukung upaya guru dalam menginovasi pembelajaran yang ada dan bisa memfasilitasi kebutuhan guru terkait invasi dan kreatifitas guru dalam pembelajaran.

\section{DAFTAR PUSTAKA}

Ahmad Susanto. Teori Belajar dan Pembelajaran di Sekolah Dasar. Kencana, 2016.

Buan, Yohana Afliani Ludo. Guru dan Pendidikan Karakter: Sinergitas Peran Guru Dalam Menanamkan Nilai-Nilai Pendidikan Karakter di Era Milenial. Penerbit Adab, 2021.

Ernawati Waridah. Kamus Bahasa Indonesia. Bmedia, 2017.

Fathurrohman, Muhammad. Belajar dan Pembelajaran Modern: Konsep Dasar, Inovasi dan Teori Pembelajaran. Garudhawaca, t.t.

Juliansyah Noor. Metodologi Penelitian: Skripsi, Tesis, Disertasi \& Karya Ilmiah. Prenada Media, 2016.

M. Ismail Makki. Konsep Dasar Belajar dan Pembelajaran. Duta Media Publishing, 2019.

Milles dan Huberman. Analisis data Kualitatif. Jakarta: Universitas Indonesia Press, 1992.

Nana. Inovasi pembelajaran digital menggunakan model pembelajaran Blended Poe2we pada mata pelajaran bahasa dan sastra Inggris di SMA Negeri 1 Ciamis untuk menghadapi tantangan abad 21. Penerbit Lakeisha, 2020.

Nurdyansyah, Eni Fariyatul Fahyuni. Inovasi Model Pembelajaran. 2016 ed. sidoarjo: Nizamia Learning Center, t.t.

Siti Aminah. Inovasi Pembelajaran Pendidikan Agama Islam di Sekolah. Sidoarjo: Nizamia Learning Center, 2019.

Siyoto, Sandu, dan Muhammad Ali Sodik. Dasar Metodologi Penelitian. Literasi Media Publishing, 2015.

Sugiyono. Metode Penelitian kuantitatif, Kualitatif, dan R \& D. Bandung: Alfa Beta, 2015.

Suharsimi, Arikunto. Prosedur Penelitian Suatu Pendekatan Praktik. Jakarta: Rineka Cipta., 2006.

Suyanto, Bagong, dan Sutinah. Metode Penelitian Sosial: Berbagai Alternatif Pendekatan. Prenada Media, 2015.

syafrudin, musiono, dan Asrul. Inovasi pendidikan. Medan: Perdana Publishing, 2012.

Wina Wijaya. Kurikulumdan Pembelajaran(Teoritik dan Praktik kurikulum KTSP). Jakarta: Prenada Media Grup, t.t. 